\title{
THE DANGER OF THE PRIVACY "DISAPPEARANCE" DURING A PANDEMIC IN THE CONTEXT OF GLOBALIZATION AND THE GROUNDS FOR ITS LEGITIMACY: AN INSTITUTIONAL ANALYSIS
}

\author{
MIKHEIL BICHIA \\ Doctor of Law, Chief Scientist at the Institute \\ for the Research of Economic and Social problems of Globalization, \\ Visiting Lecturer at Ivane Javakhishvili Tbilisi State University, Georgia \\ mikheil.bichia@tsu.ge
}

Abstract. Protection of the private sphere has become particularly important in the context of the pandemic, due, on the one hand, to the increasing use of technical means and, on the other, to the use of personal data to prevent infection. Accordingly, the purpose of the study is to define the scope of the concept of a private sphere in order to determine which relationships the public sphere applies to and when privacy begins. In this context, it must be clarified what the reasons are for intervening in the private sphere during the pandemic and whether a limitation of the right can be considered permissible (legal).

Using normative-dogmatic, comparative, sociological methods, as well as analysis and synthesis of problems, it was established that the public and private spheres intersect in the information society, which makes it difficult to separate these spheres. However, the increased use of technology during the pandemic was found to pose a greater threat of interference in the private sphere. In this regard, it is important to establish strong and effective cybersecurity mechanisms. Thus, it is true that technological development benefits society and is perceived as a good thing, but at the same time contains the threat of invasion of privacy. This is especially true for the use of personal data during a pandemic to ensure public health. In this case, a conflict of interest arises between the private sphere and public health, which must be resolved by careful examination of the case and taking into account the principle of proportionality, so as not to violate an unreasonable right.

A study of European practice has shown that interference in the private life is permissible if the restriction of the right (a) legally, (b) serves the legitimate public interest, (c) such restriction is necessary in a democratic society through the application of other, less restrictive measures. In this regard, it is advisable to determine the priority interest on the basis of a scrupulous analysis using the weighing method and the circumstances outlined above, which will prevent unreasonable interference with someone's rights.

\section{KEYWORDS: PRIVACY, PERSONAL DATA, TECHNOLOGICAL DEVELOPMENT, LEGALITY OF INTERVENTION.}

For citation: Bichia M. (2021). The danger of the privacy "disappearance" during a pandemic in the context of globalization and the grounds for its legitimacy: An institutional Analysis, Globalization and Business, №11, 43-49.

https://doi.org/10.35945/gb.2021.11.005

In a pandemic, social relations are undergoing a radical modification, which largely leads to the active use of technological means. In order to prevent the spread of COVID-19, direct relationships between people have been replaced by relationships at a distance, maintained by a computer system. Consequently, most people's work relies heavily on the technical means and proper functioning of the Internet. However, the question arises: is the use of technological means beneficial or does it increase the risks of disruption?

These problems have a direct impact on the legal space and raise the question of a new regulation of social relations. In this context, the protection of the private sphere became relevant because privacy was opposed to the societal sphere, and a person had to perform public and societal duties from his home almost all day long.

The purpose of the research is, first of all, to briefly define the essence of the private and public spheres in order to find out when the private sphere is formed and when the public sphere begins. During a pandemic, privacy is particularly affected by the fulfillment of official or societal functions at home, making it difficult to draw the line between the public and private spheres. Therefore, it is necessary to determine whether it is permissible to interfere in personal life during a pandemic. 
At the same time, the issue becomes more relevant in the wake of the development of public relations, because as a result of democratic processes, the individual with his personal or sensitive areas is considered a central part of protection. However, in the conditions of a pandemic, the personal sphere of the person often disappears and therefore its encroachment is made easier. In this regard, the aim of the study is to determine the scope of the private life protection in the conditions of a pandemic according to the international standard. Hence, it is to be examined to what extent certain restrictions on the right to privacy and freedoms of action in general can be applied within the framework of international requirements.

These problems raised are investigated with the help of normative-dogmatic, sociological, comparative, analysis and synthesis methods.

\section{Content of public and private spheres}

The public sphere includes everything that is not private (Schiedermair, 2012:9), more specifically, a space where people have the right to track or listen to an individual. In this context the public is the antonym of private (Hornby, 2002:10221023). In a broad sense, public sphere and societal life are identical in content, they have a common goal - to perform a public function. However, in a narrow sense, the public and societal spheres are separated from each other, in particular, the public sphere is related to fulfilment of the governmental or societal (non-governmental) functions (Lesch, 1998). Relationships related to fulfilment of the non-governmental duties are, by their nature, still societal, but not an integral part of private life.

In this age of technology, the private and public spheres are not diametrically opposed to each other, which is why they often intersect. It is especially difficult in the media to determine whether a particular issue belongs in the public sphere or in the sphere of private life (Lesch, 1998). But it is important to find out where the line between public and private spheres goes.

As for privacy, this is an area that is not public (Schiedermair, 2012:9), i.e. an area free from society or public interest, which combines private space, a place space to be alone, secret, personal and particularly sensitive aspects, including intimate relationships (Bichia, 2013). At the same time, it is a private field, that allows a person to be left alone and freely formulate thoughts (Schaar, 2007:19). Privacy is an important part of human's autonomy and autonomy cannot exist without the private sphere. Consequently, the loss of privacy poses a threat to the violation of fundamental human values. It entitles an individual to control information related to it, including restricting access to that information (Demirsoy and Kirimlioglu, 2016).

Thus, taking the different scope of intervention in one or another private sphere and the specifics of their protection, it is advisable to draw up a typology of these spheres: First of all, the most extensive is the private sphere, which includes relationships built between people on a non-pub- lic basis, such as property, personal or intimate spheres of a private nature, and other manifestations of a private relationship. However, it is true that all personal is private, but not vice versa. However, sometimes in the context "private" can be replaced by "personal" (Bichia, 2011). Personal life is a part of private life and includes the individual field of a person already isolated from other people, his/her spiritual and personal aspects, which relate to physical and moral integrity, personal autonomy, the means of developing individuality. As for the intimate sphere, it is considered to be the narrowest and most sensitive private sphere (Bichia, 2012:121, 327), which includes sex life, personal confidential data (Results of the medical examination, opinions expressed during the confession, information provided to the lawyer) (Peyer, 2007), and information about the state of health. That is why intimate sphere is most inaccessible to the public. Thus, the private and personal spheres are as related to each other as the general and specific, type and form (Bichia, 2012:121, 327).

\section{Boundaries of public and private spheres in the information society}

Private life experiences daily "erosion", which is a natural process: In the context of technological development, reasonable expectations of privacy are also changing (Koops and Leenes, 2005). With the development of a networked society, the privacy has narrowed and public life has been taken over to such an extent that some scholars have recognized private life as "dead" (Froomkin, 2000:1461).

Especially important in this context is one of the most important manifestations of privacy - informational privacy (Rössler, 2001:17; Weber, 2007:3), which is associated with the protection of personal data (Bichia, 2017). According to the Law of Georgia, any information relating to an identified or identifiable individual is personal (Article 2 (a) of the Law of Georgia on Personal Data Protection, 2011).

"Any information" implies an information of different types, formats and contents. Personal data can be objective (for example, notice about student status or payroll) and subjective - opinions, evaluations given in the context of information (e.g., recommendation on hiring someone). In that sense, it doesn't matter if the information is true (Tsanava, 2013; Directive 95/46/EC of the European Parliament and of the Council). Accordingly, to treat information as personal data, it should refer not only to information taken separately, but to information that relates to a particular individual and enables its identification (Nougrères, 2016:157). The individual, to whom the information relates, must be identified or identifiable, otherwise such information will not be personal (Tsanava, 2013). Data can be anonymous and pseudonymous. Data are anonymised if it no longer contains any identifiers, and data may be pseudonymised when identifiers are encrypted. Unlike anonymous data, pseudonymised data belong to personal data. As far as identification is concerned, a natural person is identified if information about his identity is known, and an identifiable natural person will be considered as one who can be defined as a result of seeking additional 
information (European Union Agency for Fundamental Rights and Council of Europe, 2018). As stated in European Union law, the protection of personal data applies only to individuals and the person is the sole beneficiary of the protection of personal data. The General Data Protection Regulation (GDPR), Council of European Law, and in particular the 108th Modernized Convention, defines personal data as any information relating to an identifiable and identifiable individual. This person is referred to as the data subject (European Union Agency for Fundamental Rights and Council of Europe, 2018:83-84) who primarily determines the availability of his or her personal data.

In the current context of commercialization, personal data are defined as a part of the broader concept of privacy and it is believed that the protection of their data can be increased more effectively if these data are recognized as property rights (Prins, 2006). So sometimes the economic aspects are combined in private life (Tzanou, 2017). However, in the era of technological development, there is a great danger of invading the personal sphere. This threat is posed by technological progress, economic interests, state control and the growing interests of the people, public disclosures, and more (Schaar, 2007:15).

In this case, the subjects of civil relations have the opportunity to carry out any action prohibited by law, even if it is not directly provided by law (Article 10 (2) CCG). However, the abuse of this freedom is prohibited by imperative norms (Article 10 (3) CCG). Private autonomy of one person is restricted by private autonomy of another, and freedom of another may be restricted by societal or public interest (Paulus and Zenker, 2001). The point is that every freedom is limited by responsibility, by the rule of law. Unrestricted freedom that violates private interest creates not a case of conflict of interest, but a violation of private interest (Kübler, 1999). Consequently, a balance of interests is achieved by maximizing the protection of these boundaries, otherwise a tortious liability may arise in the event of a breach (Article 992 CCG 992).

\section{Public health - the basis for legitimizing the encroachment of private sphere during COVID-19}

In February 2020, when the first deaths from COVID-19 were reported in France and the number of positive cases was very high in Italy, the pandemic was considered a serious problem in Europe. Various European countries in the Schengen area have applied to businesses for data transmissions, in particular, in early March, anonymous data exchanges between businesses and the government were exchanged to track the spread of COVID-19 and track the movement of people. Anonymous phone location data used by the governments of Belgium, Austria, Estonia, France, Germany, Latvia, Greece, Portugal, Italy and Spain (Klonowska and Bindt, 2020: $2-3)$. It is true that in this case a large part of the data is available to the authorities of different countries, but the data were used in compliance with the principles of confidentiality, transparency and efficiency. It was determined that anonymity was necessary in connection with the lawfulness of the use of such data. It was also found that the use of telephone location data during the pandemic was effective and unprecedented in both informing about the spread of the virus and stopping its spread, narrowing the circle of infected people. This method also has a preventive function (Klonowska and Bindt, 2020:11).

If we look at the US, $43 \%$ of the various business sectors here have closed for some time, continuing to operate for approx. $40 \%$. This was a shock to relatively small enterprises, the analogue of which is not sought after the Great Depression of the 1930s. Before the pandemic these firms had little money. They will either have to drastically reduce costs, or take out additional loans or declare themselves bankrupt (Bartik Alexander W., Bertrand M., Cullen Zoë B, Glaeser Edward L., Luca M. and Stanton C., 2020: 17656-17666). In addition, public order police on U.S. soil have been tasked with protecting social distance. It was decided that officers should spend more time in patrol cars and have less contact with members of the public. Also, in order not to disrupt the connection between the Washington police and the public, the following approach was adopted: The Columbia District Police organized meetings in the form of a conference (and not direct meetings) with the public (Hermann, P., Morse, D., \& Jackman, T. 2020; Jennings G. Wesley, Perez M. Nicholas, 2020).

In addition, restrictions and quarantine rules during a pandemic can also pose a threat to constitutional rights. However, these rules can also be a powerful tool to stop the negative impact of the pandemic on our lives and reduce its economic consequences. To this end, rules were adopted that should have been applied to the "crisis regime" for some time (Boon, Brunnermeier, Eidenmueller, Enriques, Gurrea-Martínez, Judge, Landau, Pagano, Reis \& Zwieten, 2020).

As a result of these restrictions, the hotel business, transport and leisure, tourism and various events industry were severely affected (Leopoldina Nationale Akademie der Wissenschaften, 2020:15). Because of these and other negative consequences, the coronavirus pandemic is considered to be "the darkest hour of humanity" since World War II (Berger, Behn, 2019-2020:79).

All this led to the fact that public relations shifted to the home and it became necessary to perform labor duties at home. For example, in Latvia, as in many other countries, during the pandemic, three ways of performing official functions were activated: a. Doing work from home; B. Flexible work schedule and c. Short-term work (Rödle \&Partner, 2020:19).

Thus, the private sphere was obviously narrowed. The fact is that the right to privacy can be restricted, especially during a pandemic, when Internet access is high. The Constitution of Georgia allows the restriction of private life, if it is in accordance with the law and is aimed at the protection of the necessary state or public security or the rights of others in a democratic society (Constitution of Georgia, Article 15 (1)). According to paragraph 2 of the same article, the right to privacy and communication may be restricted only when it is not contrary to the law and serves the necessary state or public safety or the protection of the rights of others in a democratic society, with or without a court order, if this is 
due to an urgent need established by law (Article 15 of the Constitution of Georgia, August 24, 1995 (as last amended), N786-rs). It is urgent that the protection of the public interest recognized by the Constitution within the principle of proportionality is impossible for objective reasons without the immediate restriction of the private interest. Clearly and unequivocally, there should be little likelihood of this public interest being protected in any other way. In case of urgency, the time is so short that immediate action is necessary and it is impossible to obtain a judge's order to restrict the right (Judgment of the Constitutional Court of Georgia N1/3/407 of 26 December 2007).

According to Article 8 (2) of the European Convention on Human Rights, public interference with the right to privacy is permissible if such interference is carried out in accordance with the law and is necessary to achieve public objectives in a democratic society. Such legitimate public interest is considered to be public safety and health.

The Additional Protocol to the American Convention on Human, Economic, Social and Cultural Rights (Article 10), known as the San Salvador Protocol, states that everyone has the right to health. It refers to having the highest quality physical, mental and social well-being. However, in order to ensure health care, the Contracting Parties agree to recognize public health as a public good (Additional Protocol to the American Convention on Human Rights in the Area of Economic, Social and Cultural Rights "Protocol of San Salvador"). According to the Law of Georgia on Public Health, public health protection is a set of measures aimed at improving the health of the population, preventing and controlling diseases (Law of Georgia on Public Health, Article 3 (a), 27 June 2007, N5069-rs).

The fact is that collecting data on the movement or health of people during a pandemic can be important for protection of public health. It is advisable for countries to use testing, isolate infected people and determine who they have had contact with. South Korea, Singapore and Hong Kong have achieved a special effect using this method. That's what the US did not do (Long, 2020:90).

The case law of the European Court of Human Rights has clarified that the storage of personal data (fingerprints and DNA) is justified by the cumulative existence of three preconditions: (a) intervention should be in accordance with the law. The law must be precise and clear. In this case, the scope of these measures, the rules of their application and the minimum guarantees of protection will be clearly and in detail defined for the storage and use of personal data; (b) Intervention must be necessary in a democratic society and (c) aimed at achieving a legitimate aim. In particular, for an interference with the law to be considered admissible, it must serve a legitimate purpose, such as preventing crime by identifying new offenders. However, when the state recognizes the leading role in the development of new technologies, it must also take special responsibility to establish a fair balance in this regard. As for the direct storage of data, it should be proportionate to the purpose of its extraction and limited in time (S. and Marper v. the United Kingdom, 04/12/2008).

The principles of the internationally recognized Syracuse stipulate that a restriction of a right is permissible if: $\mathbf{1}$. the restriction is established by law; 2 . The restriction serves a common legal interest; 3 . Restriction is necessary to achieve the goal in a democratic society; 4 . There is no less restrictive measure to achieve this goal; 5 . Restriction is not arbitrary, unreasonable or otherwise discriminatory. The existence of restrictions is largely dictated by public health needs (Akhvlediani, 2011:133-139). We find a similar record in the legislation of Georgia (Law of Georgia on Public Health, Article 453 (3), 27 June 2007).

In one case in Germany, it was found that while a ban on overnight stays for tourists was somewhat of a serious violation of professional freedom and property rights, but such an intervention is justified, because it serves a legitimate purpose - to prevent new cases of coronavirus infection and to reduce the spread of COVID-19. However, the principle of proportional treatment should not be violated in relations with different business sectors. Also, it was determined that light measures do not cause immediate results and the ban is temporary in nature (Verwaltungsgericht Berlin, Entscheidung vom 20.05.2020 - VG 14 L 97.20).

Like other countries trying to limit the spread of the virus, Germany immediately began large-scale testing to investigate permanent contacts. Early measures were taken in the country to protect the elderly population, thus maintaining a low level of infection of this vulnerable group in the society (Sauerbrey, 2020). Consequently, good results have been reported in Germany: large-scale testing, social distance protection, and access to most hospitals (so large that it receives patients from France, Italy). Germany has become an example of fighting the virus (Fasciaux, 2020).

Germany has considered a proposal to issue an "immunity certificate" if people were tested for antibodies to the virus. This eliminates the need for quarantine restrictions. However, according to the German newspaper "Spiegel", the Helmholtz Center for Infection Research in Braunschweig wants to distribute hundreds or thousands of antibody tests in the coming weeks, so that people can get out of quarantine restrictions. Italy has a similar policy (Long, 2020:93).

However, the European Court has made it clear that unless it is necessary to disclose a person's health and lifestyle in order to ensure public health and safety, it is advisable not to disclose such data. The state should have an effective mechanism to prevent the publication of health information through the press (Biriuk v. Lithuania, 25/11/2008). A person should be not means to an end but means to an end (Pfordten Dietmar von der, 2009:11). Consequently, if personal data are not used as means to an end, human dignity will also not be considered violated and will be protected.

The need to protect privacy and care for cybersecurity are intertwined problems. The issue is relevant in the context of technological development, which ultimately relates to the relationship between business and consumers on issues of personal data protection and threat protection. It is desirable to develop new policies in line with new challenges, modify technologies and tools to protect personal data (Sun, Strang and Pambel, 2018).

The importance of the internet for modern society is growing daily. The Internet is one of the possibilities of public 
or private relations. If there is no appropriate guarantee of protection of information and anonymity of persons, communication in any field may be interrupted. To prevent this, the state has a positive obligation to respect privacy and to ensure that this right can be exercised effectively. Also, within the framework of a negative obligation, the state is obliged to ensure non-interference with constitutional rights and protection of the individual (Judgment of the Constitutional Court of Georgia 241/2/519 of 24 October 2012).

However, the use of digital outlets has increased during the pandemic. According to the German Social Security Code (Socialgesetzbuch V-SGB V), people have the right to receive digital health services. However, digital outlets also carry risks associated with the theft of personal data (Gerke, Stern, Minssen, 2020).

The more developed the state, the more it depends on digital technologies. That is why the importance of cyber security is paramount. An unprotected computer system can lead to catastrophic consequences. Cyber security is aimed at ensuring the security of the assets of consumers and organizations and maintaining security in the cyber environment from risks (Napetvaridze and Chochia, 2019).

Naturally, restrictive measures by the state in the private sphere can also lead to the invasion of privacy. It is true that the delegation of certain powers by the legislature to the executive is justified in the public interest (Judgment of the Constitutional Court of Georgia N1/1/1505/1515, 1516, 1529 of 11 February 2021). It is important, however, that Parliament does not relinquish its core function and that it is possible to balance the authorities in such a way as to exclude the existence of immeasurable powers in the hands of one branch of government (Different opinion of the Judge of the Constitutional Court, Giorgi Kverenchkhiladze on the case N1/1/1505, 1515, 1529).

For the protection of personal data, it is advisable to set reliable and strong passwords that include at least 12 characters, in which, in addition to letters, numbers and symbols will be represented. It would also be good to instruct employees to change passwords regularly. Data protection will be limited by the use of highly privileged accounts and the number of failed logins, and more (Georgia Department of Law - Consumer Protection Division).

It should be noted that after the coronavirus, the challenges posed by the pandemic to the protection of personal information will not disappear anywhere. This includes giving consent, storing and disseminating data in the database, transferring personal data for instant response to infections, and more. Thus, after the pandemic is over, it is advisable for experts to reflect on this problem and manage to balance personal data protection in the face of public health threats, even in terms of future preparedness (Long, 2020:97).

As Froomkin notes, the development of technology poses a greater threat to interference in the private sphere. Consequently, the rapid pace of invention and application of technology is increasingly narrowing the privacy. Therefore, in the wake of the development of technology, it is necessary to have the appropriate legal answers immediately, otherwise the issue of protection of the private sphere will be too late (Froomkin, 2000:1461, 1543).

\section{CONCLUSION}

As the research shows, the protection of information privacy in the conditions of the pandemic has become especially important. The point is that in the information society, the public and private spheres are intertwined, which makes it difficult to draw the line between them. The study confirmed that the private sphere is built on non-public sources and is a space free from public scrutiny based on autonomy, which includes property, family, intimate and other private matters. However, in a pandemic, when a person performs his / her duties from home, the private sphere is invaded and in fact disappears for the most part. When it comes to providing medical care, there is also a high probability that personal space will not be protected or personal data will be released without permission. This is even more evident if we consider remotely consulting or forwarding personal data within a medical service, which can be obtained by hacking third-party programs. In this way, the scope of the notion of private life may in fact be greatly narrowed, and in some cases may be extended only to the intimate realm as the most deeply private realm, however, sometimes even the personal sphere may disappear and be replaced by the public sphere. Therefore, questions arise: to what extent is it permissible for the public sphere to override such a private sphere? Does the disappearance of private life have a legitimate basis?

In addition, it turned out that in this case, two interests collide - the human's private sphere and public health. In this kind of value conflict between private and public interests, the priority of ensuring public health has been identified, which is dictated by the survival of the more weight good. It is advisable, however, that the principle of proportionality should be taken into account in the collision of these two goods, so as not to unjustifiably violate any right, including the freedom of a person's private life.

The violation of the right should be considered legitimate if the cumulative preconditions are met, by which the Law of Georgia on Public Health is as close as possible to the European approaches. These prerequisites are: 1 . Restriction is provided by law; 2 . The purpose of restricting the right is to protect the common lawful interest; 3 . Such a restriction is necessary to achieve the goal in a democratic society; 4 . The use of less restrictive measures to achieve this goal is excluded; 5. Restriction is not arbitrary and unreasonable (Akhvlediani, 2011:133-139). However, it is advisable to use the weigh-in method to determine the priority interest based on a scrupulous analysis and to check the circumstances presented above, which will prevent unjustified interference with someone's rights. 


\section{REFERENCES:}

Additional Protocol to the American Convention on Human Rights in the Area of Economic, Social and Cultural Rights "Protocol of San Salvador", Adopted in San Salvador on November 17, 1988, <https://legal.un.org/avl/studymaterials/rcillaac/2016/book1_2.pdf> (03.12.2020).

Akhvlediani, M., (2011). Constitutional Guarantees of the Right to Health Care in Georgia, Doctoral Dissertation, Tbilisi (In Georgian).

Bartik, A. W., Bertrand, M., Cullen, Zoë B., Glaeser, E. L., Luca, M. and Stanton, C., (2020). The Impact of COVID-19 on Small Business Outcomes and Expectations. "Proceedings of the National Academy of Sciences". 117, N30:17656-17666, https://doi.org/10.1073/pnas.2006991117 (04.05.2020).

Bichia, M., (2011). Scopes of the private life concept according to Georgian Legislation and judicial Practice, "Journal of Law", N1:58-59 (In English).

Bichia, M., (2012). Protection of Personal Life according to Georgian Civil Law, Tbilisi, Bona Causa:121, 327 (In Georgian).

Bichia, M., (2013). Conflict of Values between the Freedom of expression and right to privacy, "Justice and Law", N3:131 (In Georgian).

Bichia, M., (2017). The Problem of Civil Legal Protection of Personal Data in the Internet Universe, In: VIII International scientific and practical conference: "Internet and society":35-42 (In Georgian).

Biriuk v. Lithuania, 25/11/2008.

Boon, G.-J., Brunnermeier, M. K., Eidenmueller, H., Enriques, L., Aurelio, G.-M., Judge, K., Landau, J.-P., Pagano, M., Reis, R. \& Zwieten, K., van. (2020). The Covid-19 Pandemic and Business Law: A Series of Posts from the Oxford Business Law Blog, Oxford Legal Studies Research Paper NO. 15:1-34.

Constitution of Georgia, Article 15, 24 August 1995 (Last edition), N786-rs (In Georgian).

Demirsoy, N. and Kirimlioglu, N., (2016). Protection of privacy and confidentiality as a patient right: physicians' and nurses' viewpoints, Biomedical Research-India, Vol. 27, Issue 4:1437-1438.

European Union Agency for Fundamental Rights and Council of Europe. (2018). Handbook on European data protection law, Luxembourg:83-88.

Fasciaux, N., (2020). What is Germany doing better to save lives from COVID-19? https://storytracker.solutionsjournalism.org/ collections/al0c8q6ql2 (07.12.2020).

Froomkin, A.M., (2000). "The Death of Privacy?" Stanford Law Review, 52:1461-1543.

General Data Protection Regulation (GDPR), Directive 95/46/EC of the European Parliament and of the Council of 24 October 1995.

Georgia Department of Law - Consumer Protection Division, Cybersecurity in Georgia, A guide for small Business, Non-profits and Places of Worship, 7, http://consumer.ga.gov/uploads/pdf/Cybersecurity_in_Georgia.pdf

Gerke, S., Stern, Ariel D., Minssen, T., (2020). Germany's digital health reforms in the COVID-19 era: lessons and opportunities for other countries, npj Digital Medicine, 94:1, 5.

Hermann, P., Morse, D., \& Jackman, T., (2020). Patrolling the beat while keeping a distance: Police officers face new rules, rhythms amid pandemic. The Washington Post. https://www.washingtonpost.com/local/public-safety/patrolling-thebeat-while-keeping-a-distance-police-officers-face-new-rules-rhythms-amid-pandemic/2020/03/27/334b3602-6afc11ea-abef-020f086a3fab_story.html (08.09.2020).

Hornby, A., (2002). Oxford Advanced Learner's Dictionary, Oxford, New York, Oxford university press.

Jennings, G. W. and Perez, M. N., (2020). The Immediate Impact of COVID-19 on Law Enforcment in the United States, American Journal of Criminal Justice, 10.1007/s12103-020-09536-2.

Judgment of the Constitutional Court of Georgia 241/2/519 of 24 October 2012, Case of the Georgian Young Lawyers' Association and Citizen of Georgia Tamar Chugoshvili v. the Parliament of Georgia (In Georgian).

Judgment of the Constitutional Court of Georgia N1/1/1505/1515, 1516, 1529 of 11 February 2021, Case of Paata Diasamidze, Giorgi Chitidze, Eduard Marikashvili and Lika Sajaia v. the Parliament of Georgia and the Government of Georgia (In Georgian).

Judgment of the Constitutional Court of Georgia N1/3/407 of 26 December 2007, Case of the Georgian Young Lawyers' Association and Citizen of Georgia Ekaterine Lomtatidze v the Parliament of Georgia, II-26 (In Georgian).

Klonowska, K. and Bindt, P., (2020). The COVID-19 pandemic: two waves of technological responses in the European Union, The Hague Centre for Strategic Studies, 11.

Koops, B.-J. and Leenes, R., (2005). 'Code' and the slow erosion of Privacy, 12 Michigan Telecommunications and Technology Law Review:184.

Kübler, Fr., (1999). Ehrenschutz, Selbstbestimmung und Demokratie, NJW, 52. Jahrgang, 1. Halbband, 1285 (In German).

Law of Georgia on Personal Data Protection, Article 2 (a), 28 December 2011 No 5669-ES (In Georgian).

Law of Georgia on Public Health, Article 3 (a), 45³ (3), 27 June 2007, No5069-rs (In Georgian).

Lesch, W., (1998). Medienethik zwischen öffentlichem und Privatem, Im Zoom K\&M Nr. 11, 45, <http://www.medienheft.ch/ uploads/media/11_ZOOM_KM_08_Walter_Lesch_Medienethik.pdf> (06.04.2011) (In German). 
Long, C., (2020). Privacy and Pandemics, In: Pistor, Katharina, "Law in the Time of COVID-19", 90-97, <https://scholarship. lawcolumbia.edu/books/240> (05.12.2020).

Napetvaridze, V. and Chochia, A., (2019). Cybersecurity in the making - policy and law: A Case study of Georgia, ICLR, Vol. 19, No. 2, S. 156.

Nougrères, A. B., (2016). Data Protection and Enforcement in Latin America and in Uruguay, In: Wright D. and Hert P. De (editors), Enforcing, Privacy, Springer, Cham.

Paulus, G. Chr. and Zenker, W., (2001). Grenzen der Privatautonomie, JuS, 41. Jahrgang, Heft 1, S. 2-4 (In German).

Peyer, C., (2007). Die Bildberichterstattung über Prominente im Spannungsfeld von Privatsphärenschutz und Pressefreiheit, unter besonderer Berücksichtigung der „Caroline von Hannover“- Entscheidung des EGMR und der Reaktionen in der deutschen Lehre, Seminar zum Thema: „Menschenrechtsschutz in Europa“, Wintersemester, 13 (In German).

Pfordten, Dietmar von der., (2009). Zur Würde des Menschen bei Kant, In Fünf Untersuchungen "Menschenwürde, Recht und Staat bei Kant", 1. Auflage, Mentis, Paderborn, Verlag C.H. Beck (In German).

Prins, C., (2006). "When personal data, behavior and virtual identities become a commodity: Would a property rights approach matter?" SCRIPT-ed, Volume 3, Issue 4, 278.

Rödle \&Partner., (2020). Coronavirus (COVID -19), It Is Treatable - State Aid Programs To Mitigate Adverse Effects On Your Business Latest updates on current status | Nordic-Baltic region:7-8.

Rössler, B., (2001). Der Wert des Privaten, Frankfurt: Suhrkamp (In German).

Sauerbrey, A., (2020). "Germany has relatively few deaths from Coronavirus. Why?" The New York Times, https://storytracker. solutionsjournalism.org/stories/germany-has-relatively-few-deaths-from-coronavirus-why (07.12.2020).

Schaar, P., (2007). Das Ende der Privatspähre, Der Weg in die Überwachungsgeselschaft, München (In German).

S. and Marper v. the United Kingdom, 04/12/2008.

Schiedermair, S., (2012). Der Schutz des Privaten als internationals Grundrecht, Mohr Sieback Tübingen (In German).

Sun, Z, David Strang K. \& Pambel F., (2018). Privacy and security in the big data paradigm, Journal of Computer Information Systems:1-9, DOI: 10.1080/08874417.2017.1418631

Tzanou, M., (2017). The Fundamental Right to Data Protection, Oxford and Portland, Oregon, pp. 14-15.

Verwaltungsgericht Berlin, Entscheidung vom 20.05.2020 - VG 14 L 97.20 (In German).

Weber, K., (2007). Grundlagen der Informations-ethik, China, Konrad Adenauer Stiftung, September (In German). 